\title{
A Long Non-coding RNA and its Potential Role in Human Myeloid Leukemia
}

\author{
David Reisman* \\ Department of Biological Sciences, University of South Carolina Columbia, USA
}

*Corresponding author: David Reisman, Department of Biological Sciences,

University of South Carolina Columbia, USA.

Received Date: February 23, 2021

Published Date: March 08, 2021

\begin{abstract}
Over the past ten to fifteen, IncRNAs have been discovered to be expressed widely in eukaryotes and function as regulators of many diverse biological processes. We have identified a novel long non-coding RNA (IncRNA) that, as our early evidence indicates, participates in maintaining the undifferentiated and proliferative state of human myeloid leukemia-derived cells. With the accumulating evidence that lncRNAs act in regulating genes required for proper cell differentiation, the enhanced expression of the lncRNA we identified in myeloid leukemias and its apparent role in maintaining the proliferative state of these cells is quite significant, both in terms of understanding lncRNA function, and the potential design of novel therapeutics for myeloid leukemias.
\end{abstract}

Keywords: Long noncoding RNA; Leukemia; Differentiation

\section{Introduction}

Over the past decade, long non-coding RNAs (lncRNAs) have been discovered to function as regulators of gene expression and numerous biological processes. They are transcribed from loci throughout the genomes of most eukaryotes [1-7]. and reports indicate that many IncRNAs are involved in the regulation of pluripotency and differentiation [8-14]. Although the mechanisms by which these IncRNAs function are still being explored, one model that has emerged states that nuclear lncRNAs modulate gene expression through interactions with histone modifying proteins and/or transcription factors [6-7, 12, 15-18].

Other IncRNAs function in the cytoplasm [19-21]. Lnc-MD1, for example, is a muscle-specific IncRNA that regulates muscle differentiation by binding to microRNAs (miRNA) and limiting their availability to regulate gene expression [9]. Another IncRNA, TINCR, is induced during epidermal differentiation and interacts with a number of differentiation-specific mRNAs to regulate their stability
[10]. These, and other results, demonstrate that IncRNAs can act to regulate genes required for cell differentiation through multiple mechanisms [13, 21-23]. Furthermore, enhanced expression of some IncRNAs have been shown to contribute to certain cancers as well. SAMMSON for example, is a lncRNA expressed at elevated levels in melanomas and its inhibition resulted in decreased viability of human melanoma-derived cells [24]. Likewise, numerous lncRNAs, including the one we describe here have been implicated in contributing to acute myeloid leukemia [25-28].

Identification of a IncRNA transcribed from exon 1 of the p53 gene

A few years ago, as described below, we identified a lncRNA, designated as lncRNAp53Int1, that exhibits enhanced expression in myeloid leukemias, that functions to maintain the proliferative state of leukemic cells [25]. To date, our findings indicate that IncRNAp53Int1 functions in the cytoplasm, and through interactions 
with as yet unidentified RNA molecules or proteins, contributes to oncogenic transformation by suppressing the differentiation of myeloid progenitor cells. Inhibiting its activity or the activity of its targets is predicted to lead to differentiation and cessation of proliferation.

\section{IncRNAp53int1 is linked to the differentiation of human myeloid leukemia cells}

A number of years ago, we identified a transcription unit located in the 1st intron of the human p53 tumor suppressor gene that encoded a RNA transcript that had no identifiable open reading frame for protein synthesis [28]. This transcript was later classified as a IncRNA [19, 30-31] and is listed as GC17M015273 in the GeneCard Human Gene Database (http://www.genecards.org) and NONHSAG020729 in NONCODE v4 (http://www.noncode. org). The IncRNAp53Int1 transcript is approximately 1125 nucleotides in length, is polyadenylated, and contains no introns. While there appears to be no functional or regulatory relationship to p53 itself, the abundance of this IncRNA is significantly reduced during differentiation of human myeloid leukemia cells [25]. We hypothesize that IncRNAp53Int1 plays a crucial role in maintenance of the undifferentiated proliferative state in myeloid leukemia. That IncRNAp53Int1 is expressed in immature cell types is supported by IncRNA expression data collated in various publicly available databases. Although expressed in a variety of human tissues, tissues found to express the highest levels of lncRNAp53Int1 include those that contain proliferative and immature cell types such as lymph node, foreskin fibroblasts and umbilical endothelial cells.

\section{Potential Therapeutics}

Myeloid leukemias are characterized by genetic alterations that lead to a complete or partial block at various stages of myeloid differentiation and subsequent proliferation of myeloid progenitor cells [32-36]. That IncRNAp53Int1 appears to block differentiation of human myeloid leukemia cells is noteworthy because the ability to induce differentiation of acute myeloid leukemias is used as one therapeutic strategy [34, 37-40]. The discovery of a regulatory role for IncRNAp53Int1 in leukemia cell differentiation and the ultimate identification of its cellular targets could provide researchers with new pathways to target in the development of novel therapeutics for acute myeloid leukemias [41-42]. Silencing this lncRNA or one or more of its interacting molecules could potentially lead to an effective way to inhibit proliferation through the induction of terminal differentiation.

\section{Acknowledgement}

DR acknowledges funding from the Children's Leukemia Research Association.

\section{Conflict of Interest}

No conflict of interest.

\section{References}

1. Guttman, Amit I, Garber M, French C, Lin MF, et al. (2009) Chromatin signature reveals over a thousand highly conserved large non-coding RNAs in mammals. Nature 458(7235): 223-227.

2. Kim ED, Sung S (2012) Long noncoding RNA: unveiling hidden layer of gene regulatory networks. Trends in Plant Sci 17(1): 16-21.

3. Rinn JL, Chang HY (2012) Genome regulation by long noncoding RNAs. Ann Rev. Biochem 81: 145-166.

4. Sabin LR, Delas MJJ, Hannon GJ (2013) Dogma Derailed: the many influences of RNA on the genome. Mol Cell 49(5): 783-794.

5. Batista PJ, Chang HY (2013) Long noncoding RNAs: cellular address codes in develpoment and disease. Cell 152(6): 1298-1307.

6. Engreitz JM, Haines JE, Perez EM, Munson G, Chen J, et al. (2016) Loca regulation of gene expression by lncRNA promoters, transcription and splicing. Nature 539(7629): 452-455

7. Kopp F, Mendell JT (2018) Functional classification and experimental dissection of long noncoding RNAs. Cell 172(3): 393-407.

8. Guttman M, Donaghey J, Cary BW, Garber M (2011) lincRNAs act in the circuitry controlling pluripotency and differentiation. Nature 477(7364): 295-300.

9. Cesana M, Cacchiarelli D, Legnini I, Santini T, Athandler O, et al. (2011) A long non-codingRNA controls muscle differentiation by functioning as a competing endogenous RNA. Cell 147(2): 358-369.

10. Kretz M, Siprashvili Z, Chu C, Webster DE, Zehnder A, et al. (2013) Control of somatic tissue differentiation by the long non-coding RNA TINCR. Nature 493(7431): 231-235.

11. Wang Y, Xu Z, Jiang J, Xu C, Kang J, et al. (2013) Endogenous miRNA sponge lincRNA-RoR regulates Oct4, Nonog, Sox2 in human embryonic stem cell self-renewal. Develop Cell 25: 69-80.

12. Fatica A, Bozzoni I (2014) Long non-coding RNAs: new players in cell differentiation and development. Nature Reviews Gen 15(1): 7-21.

13. Ma XY, Wang JH, Wang JL, Ma CX, Liu FS (2015) Malat1 as an evolutionarily conserved lncRNA, plays a role in regulatng proliferation and maintaining the undifferentiated status of early-stage hematopoietic cells. BMC Genomics 16(1): 676- 689

14. Alvarez Dominguez, JR, Lodish HF (2017) Emerging mechanisms of long noncoding RNA function during normal and malignant hematopoiesis. Blood 130(18): 1965-1975.

15. Davidovich C, Cech TR (2015) The recruitment of chromatin modifiers by long noncoding RNAs: lessons from PCR2. RNA 21(12): 2007-2022.

16. Chi KR (2016) Finding function in mystery transcripts. Nature 529: 423425.

17. Long Y, Wang X, Youmans DT, Cech TR (2017) How do lncRNAs regulate transcription? Sci Adv 3(9): 1-13.

18. Statello L, Guo CJ, Chen LL, Huarte M (2021) Gene regulation by long non-coding RNAs and its biological functions. Nat Rev Mol Cell Biol 22(2): 96-118.

19. Derrien T, Johnson R, Bussotti G, Tanzer A, Djebali S, et al. (2012) The GENCODE v7 catalog of human long non-coding RNAs; analysis of their gene structure, evolution, and expression. Genome Res 22(9): 17751789.

20. Atianand MK, Hu W, Satpathy AT, Shen Y, Ricci EP, et al. (2016) A long noncoding RNA lincRNA-EPS acts as a transcriptional brake to restrain inflammation. Cell 165(7): 1672-1685.

21. Peng W, Zhang C, Peng J, Huang Y, Peng C, et al. (2020) Lnc-FAM84B-4 acts as an oncogenic IncRNA by interacting with protein hnRNPK to restrain MAPK phosphatases-DUSP1 expression. Cancer Lett 494: 94 106. 
22. Hughes JM, Legnini I, Salvatori B, Masciarelli S, Marchioni M, et al. (2015) C/EBPa-p30 protein induces expression of the oncogenic long noncoding RNA UCA1 in acute myeloid leukemia. Oncotarget 6(21): 1853418544.

23. Zeng C, Yu X, Lai J, Yang L, Chen S, et al. (2015) Overexpression of the long non-coding RNA PVT1 is correlated with leukemic cell proliferation in acute promyelocytic leukemia. J Hemat Oncol 8: 126-141.

24. Leucci E, Vendamin R, Spinazzi M, Laurette P, Fiers M, et al. (2016) Melanoma addiction to the long non-coding RNA SAMMSON. Nature 531(7595): 518-521.

25. Reisman D, Gibson A, Patel M, Wang Y (2016) Evidence for a role of a lncRNA encoded from the p53 tumor suppressor gene in maintaining the undifferentiated state of human myeloid leukemias. Gene Reports 5: 45-50

26. Cruz Miranda GM, Hidalgo Miranda A, Bárcenas López DA, Núñez Enríquez JC, Ramírez Bello J, et al. (2019) Long Non-Coding RNA and Acute Leukemia. Int J Mol Sci 20(3): 735-752.

27. Liu Y, Cheng Z, Pang Y, Cui L, Qian T, et al. (2019) Role of microRNAs, circRNAs and long noncoding RNAs in acute myeloid leukemia. J Hematol Oncol 12(1): 51-71.

28. Wang CH, Li QY, Nie L, Ma J, Yao CJ, et al. (2020) LncRNA ANRIL promotes cell proliferation, migration and invasion during acute myeloid leukemia pathogenesis via negatively regulating miR-34a. Int J Biochem Cell Biol: 119-129.

29. Reisman D, Balint E, Loging T, Rotter V, Almon E (1997) A nove transcript encoded within the $10-\mathrm{Kb}$ first intron of the human p53 tumor suppressor gene (D17S2179E) is induced during differentiation of myeloid leukemia cells. Genomics 15: 364-370.

30. Spizzo R, Almeida MI, Colombatti A, Calin GA (2012) Long non-coding RNAs and cancer: a new frontier of translational research? Oncogene 31(43): 4577-4587.

31. Zhao Y, Yuan J, Chen R (2016) NONCODEv4: annotation of noncoding RNAs with emphasis on long noncoding RNAs. Methods Mol Biol 1402: 243-254.
32. Gilliland DG, Griffin JD (2002) The roles of FLT3 in hematopeoisis and leukemia. Blood 100(5): 1532-1542.

33. Kumar CC (2011) Gentic abnormalities and challenges in the treatment of acute myeloid leukemia. Genes Cancer 2(2): 95-107.

34. Cimmino L, Dolgalev I, Wang Y, Yoshimi A, Martin GH, et al. (2017) Restoration of TET2 function blocks aberrant self-renewal and leukemia progression. Cell 170(6): 1079-1095.

35. Suzuki H, Forrest AR, van Nimwegen E, Daub CO, Balwierz PJ, et al. (2009) The transcriptional network that controls growth arrest and differentiation in a human myeloid leukemia cell line. Nature Genetics 41(5): 553-562.

36. Jimenez JJ, Chale RS, Abad AC, Schally AV (2020) Acute promyelocytic leukemia (APL): a review of the literature. Oncotarget 11(11): 992-1003.

37. Nowak D, Stewart D, Koeffler HP (2009) Differentiation therapy of leukemia: 3 decades of development. Blood 113(16): 3655-3665.

38. Sell S (2005) Leukemia: stem cells, maturation arrest, and differentiation therapy. Stem Cells Rev 1(3): 197-206.

39. Lo Coco F, Avvisati G, Vignetti M, Thiede C, Orlando SM, et al. (2013) Gruppo Italiano Malattie Ematologiche dell'Adulto.; German-Austrian Acute Myeloid Leukemia Study Group. Study Alliance Leukemia. Retinoic acid and arsenic trioxide for acute promyelocytic leukemia. N Engl J Med 369(2): 111-121

40. Su R, Lin HS, Zhang XH, Yin XL, Ning HM, et al. (2014) MiR-181 family: regulators of myeloid differentiation and acute myeloid leukemia as well as potential therapeutic targets. Oncogene 34(25): 3226-3239.

41. Sykes DB, Kfoury YS, Mercier FE, Wawer MJ, Law JM, et al. (2016) Inhibition of dihydroorotate dehyrodgenase overcomes blockade in acute myeloid leukemia. Cell 167(1): 171-186.

42. Latif AL, Holyoake TL (2016) Lifting the differebtiation embargo. Cell 167(1): 45-46. 